\title{
Unraveling the Dynamics of a Creeping Slope in Northwestern Colombia: Hydrological Variables, and Geoelectrical and Seismic Signatures
}

\author{
Juan C. Loaiza-Usuga ${ }^{1, * \mathbb{C}}$, Gaspar Monsalve ${ }^{1}$, Aleen Pertuz-Paz ${ }^{1}$, Laura Arce-Monsalve ${ }^{1}$, \\ Mateo Sanín ${ }^{2}$, León F. Ramírez-Hoyos ${ }^{1}$ (D) and Roy C. Sidle ${ }^{1,3,4}$ \\ 1 Departamento de Geociencias y Medio Ambiente, Facultad de Minas, Universidad Nacional de Colombia, \\ Medellín 050034,Colombia; gmonsalvem@unal.edu.co (G.M.); apertuz@unal.edu.co (A.P.-P.); \\ larcem@unal.edu.co (L.A.-M.); lframirezh@unal.edu.co (L.F.R.-H.); rsidle@usc.edu.au (R.C.S.) \\ 2 Departamento de Ciencias de la Tierra, Universidad EAFIT, Medellín 050022, Colombia; \\ msaninz@eafit.edu.co \\ 3 Sustainability Research Centre, University of the Sunshine Coast, Locked Bag 4, \\ Maroochydore DC, QLD 4558, Australia \\ 4 Mountain Societies Research Institute, University of Central Asia, Khorog 736000, Tajikistan \\ * Correspondence: jcloaiza@unal.edu.co; Tel.: +57-44255100
}

Received: 14 September 2018; Accepted: 20 October 2018; Published: 23 October 2018

\begin{abstract}
Mass movements are quite common in the Northern Andes and constitute one of the major hazards in the region. In particular, along valley flanks where the city of Medellin (Colombia) is located, rainfall is the main trigger of these phenomena, but little is understood about how water in the soil and subsoil behaves. In this study, we show data from some basic soil hydrology measurements and conventional geophysical surveys within a $\sim 4$ ha experimental plot that is experiencing soil creep. The seasonally wet study site has an average slope gradient of 33\%, and its surface geology consists of a series of older deposits of debris flows. Our measurements show a low surface runoff, which ranges from 4 to $11 \%$ of the rainfall; infiltration is $89-96 \%$ of the rainfall, and $15-33 \%$ corresponds to drainage water at shallow levels in the soil $(20-50 \mathrm{~cm})$; piezometric measurements reveal a mostly steady-state water table. About $14-54 \%$ of the rainfall becomes subsurface flow within the first $\sim 1-2 \mathrm{~m}$ below the surface. Geoelectrical and seismic surveys suggest small temporal changes in the properties of materials shallower than $2 \mathrm{~m}$, consistent with the steady-state water table and the permanent and high subsurface flow. These geophysical surveys also indicate the presence of a major discontinuity at $\sim 4-6 \mathrm{~m}$ below the surface, which we interpret as the limit between different prior debris flows.
\end{abstract}

Keywords: runoff; water table; soil creep; subsurface flow; piezometers; geophysical surveys

\section{Introduction}

The tropical Andes of Northern South America is highly susceptible to mass wasting, due to widespread steep slopes, unstable and erodible soils, and heavy rain. Also, population pressures are increasing the areas prone to landslides, and the losses in infrastructure amount to several billions of dollars every year; particularly, in northern South America, more than 100,000 casualties in the last 50 years can be attributed to different kinds of landslides [1]. The city of Medellín (Colombia) is located at the bottom and along the flanks of the Aburrá Valley (Figure 1). Given the mean annual rainfall of $\sim 1800 \mathrm{~mm}$, debris flows, rotational landslides, and soil creep are pervasive and frequent occurrences [2,3]. Several studies have identified rainfall and the resultant hydrologic processes as the major triggering factors for mass movements in tropical and subtropical areas [4-7]. The connection between the hydrologic cycle and the occurrence of mass wasting phenomena in the Aburrá Valley is 
clear $[3,8,9]$; the steep slopes and the intense chemical weathering are also crucial factors that promote slope instability [10].

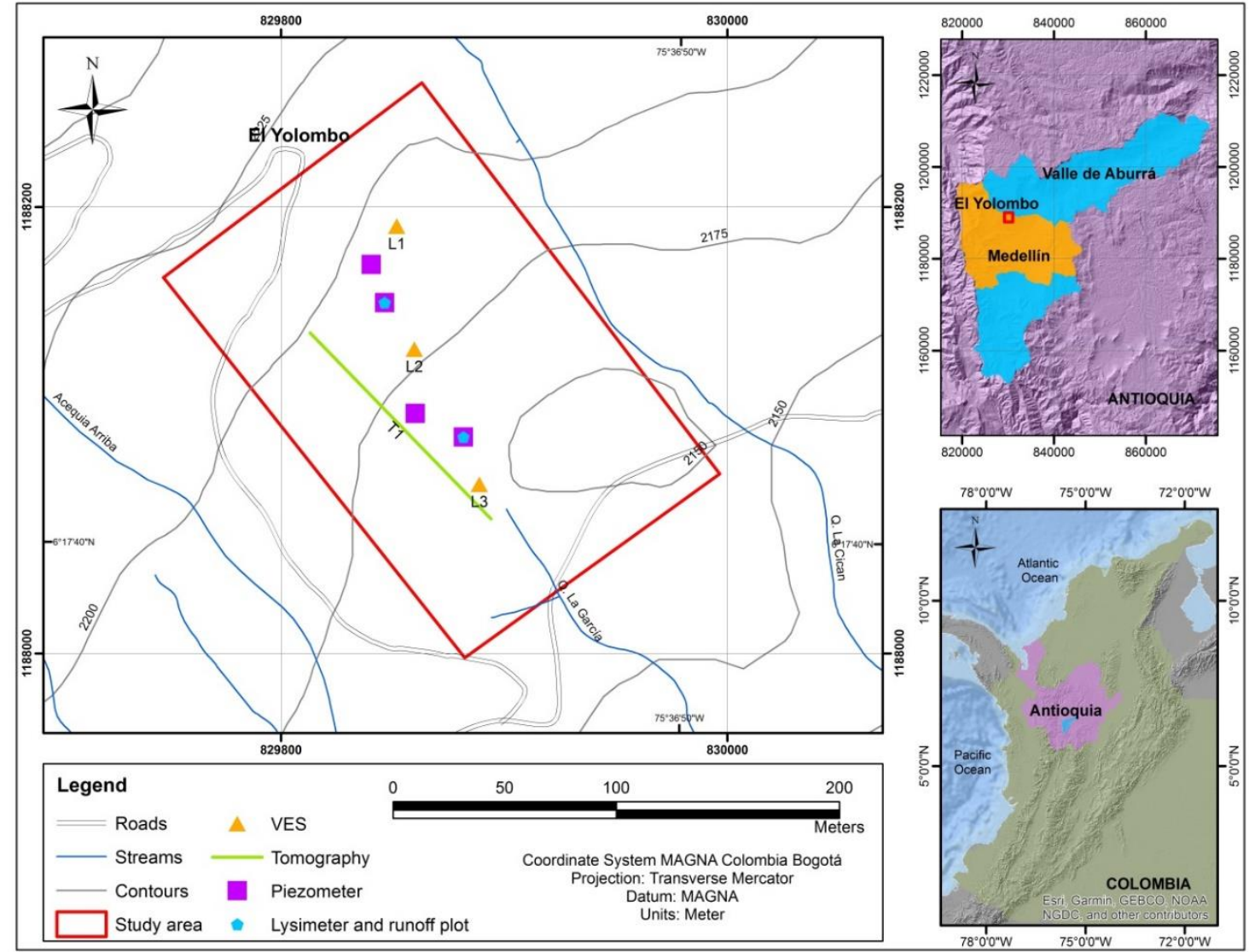

Figure 1. Location of the study area in the locality of El Yolombo on the western flank of the Aburrá Valley where the city of Medellín is located. The studied parcel is depicted with the red box. Measurement locations are also indicated. Piezometers (magenta squares) are numbered from 1 to 4, from top to bottom of the study site.

The occurrence of several recently-identified landslides in urban and rural areas of the city, as well as frequent indicators of soil creep (e.g., cracks and differential movement in roads, tilted trees and posts, cracks in houses and buildings), motivated us to select a parcel of terrain in a rural location of Medellín with strong evidence of soil creep, to initiate an exploratory study by measuring some hydrological and geophysical variables, to follow their evolution in time, and relate them with the hydrologic cycle of the site. Landslide studies in this region have focused on the statistical link between landslide triggering and rainfall, and on the influence of geomorphological and geological features in the landslide hazard [2,3,5,6,8-10]. Our intention in this study is to understand the dynamics of water in the soil mass and relate it with the behavior of the mass movement; moreover, we focus on an area of slow downslope motion (creep), where it is not possible to establish a specific moment for a landslide occurrence.

Previous studies on creeping slopes, focus on pore pressure accretion that destabilizes the slopes [11] and on the nature of subsurface hydraulics [12]. Although it is clear that pore-pressure monitoring is a key procedure to understand landslide triggering [13], we take a different approach in our measurements, and rely on the plausible hypothesis that the dynamics of soil creep is controlled by the soil water behavior. As such, we seek to develop a first-order approach of how water flows within the soil at the study site based on very simple measurements of runoff and percolation, and conventional geophysical surveys. With this in mind, and focusing on an unstable area of 
$\sim 4$ ha with a mean slope gradient of about 33\%, the aim of our study was to better understand: (1) how the soil moves downslope; (2) what soil layers are involved in the creep process; and (3) how the hydrology controls the dynamics of the movement.

\section{Study Site and Methodology}

Soil creep in the western slope of Medellín is commonly manifested as damages to roads, tilted trees and posts, scars and steps in the terrain, and severe structural deformation in houses and buildings. Intense denudation practices contribute to soil instability. To understand the dynamics of mass soil movement, we chose an $\sim 4$ ha parcel of terrain near El Yolombo (see Figure 1 for site location) that was close to affected roads and houses for our experimental site. Characteristics of the study site are shown in Figure 2. The parcel has a mean slope of about $33 \%$, is densely vegetated, and cracks and subsidence within a road located immediately downhill are evident. Native vegetation and a few planted pine trees are present on the site; there is also minor cattle grazing (one or two cows at a time). Road subsidence (Figure 2a) and tilted trees and posts (Figure 2c,d) are the main indicators of soil creep. Rainfall occurs year-round in this area, with two maxima per year. The creeping soil consists of an older debris flow deposit with a wide range of grain sizes from clay to occasional boulders of heterogeneous sizes and shapes (Figure 2e,f); the mean matrix-block ratio is between $40 \%$ and $60 \%$, with angular cobbles predominating among the blocks.

The site was instrumented in early 2016, and measurements are continuing. Two experimental closed runoff plots of 4 and $1.6 \mathrm{~m}^{2}$ were installed according to the methodology presented in [14]; the plot locations are shown in Figure 1 (blue polygons). The physical and morphological features of the soil in the two plots are listed in Table 1, following the standards in [15]. The meteorological data in the area are recorded every minute at two nearby stations and stored in the data base of the Early Warning System of Medellín and Aburrá Valley (SIATA by its acronym in Spanish). We intended to measure surface runoff every week in the wettest periods and every two weeks in the driest periods. Given the logistical limitations, it was not possible to obtain a continuous record of the measurements, so the data are limited to four time windows: September to October 2016, January to May 2017, September to October 2017, and March to May 2018. In order to estimate surface runoff, infiltration, and percolation, lysimeter measurements were also conducted during the same time periods. More specifically, the equipment used was zero-tension lysimeters [16], which were installed depending on site characteristics and soil depth. The lysimeters were rectangular boxes of $20 \times 30 \mathrm{~cm}$, designed to collect saturated flow that percolated into the soil profile. A total of four lysimeters were installed (two per plot) at various depths (Table 1). Four piezometers constructed from PVC tubes were installed along the slope (magenta squares, Figure 1). Figure 3 shows photographs of a runoff plot and a piezometer.

A longitudinal (along the slope) geo-electrical section was selected to generate a tomographic image of resistivity (green line in Figure 1) to explore the general properties of the materials up to depths of $\sim 6 \mathrm{~m}$. This experiment was run only once during the period of observation. The collection of resistivity data was conducted using a Dipole-Dipole array along a linear distance of $120 \mathrm{~m}$, and a damped least-squares method was used to invert the apparent resistivities measured in the field $[17,18]$ using RES2DINV-v3.54.44 software [19]. As such, we obtained an Electrical Resistivity Tomography (ERT) for the sampled cross-section. A total of 104 values of apparent resistivity were inverted, and 10 iterations were necessary for the inversion routine. The Root Mean Square (RMS) of the residuals (difference between measured and predicted apparent resistivities) was used as a measure of fit. Topographical data were incorporated into the inversion process and modeling.

Several Vertical Electrical Soundings (VES) were conducted at three locations within the parcel (Figure 1) at three different dates in 2016. We used the Wenner array with a maximum distance between adjacent electrodes of $7 \mathrm{~m}$; the software RESIST [20] was used to invert the apparent resistivity data and generate a simple three-layer 1D resistivity model. The residual RMS was also used as the measure of goodness of fit. Similarly, we ran conventional seismic surveys of Multichannel Analysis of Surface 
Waves (MASW) [21] to deduce a simple 1D structure of shear wave speed (or rigidity) at the three locations chosen for the VES (Figure 1). Even though we could not take these measurements at the same three times as the VES, we also carried out the seismic surveys at three different times within the year, using an array of 24 geophones with a spacing of $0.5 \mathrm{~m}$ and an offset distance of $1 \mathrm{~m}$; we used the software winMASW [22] and the inversion method of Dal Moro et al. [23].

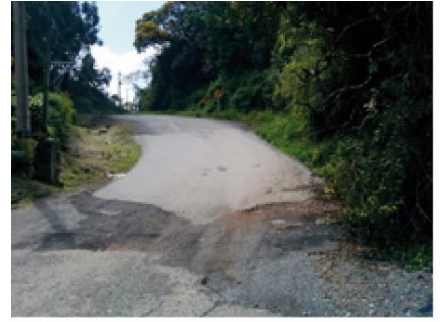

(a)

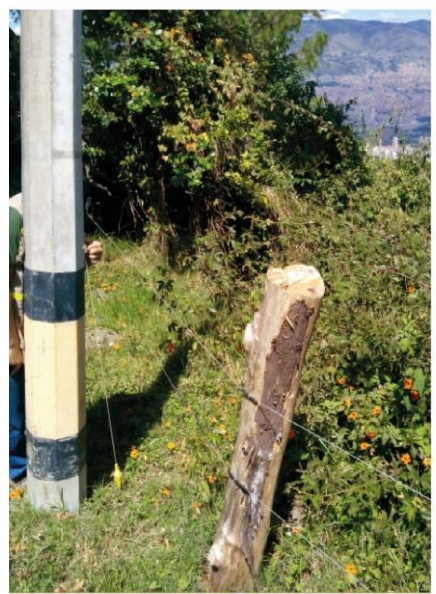

(c)

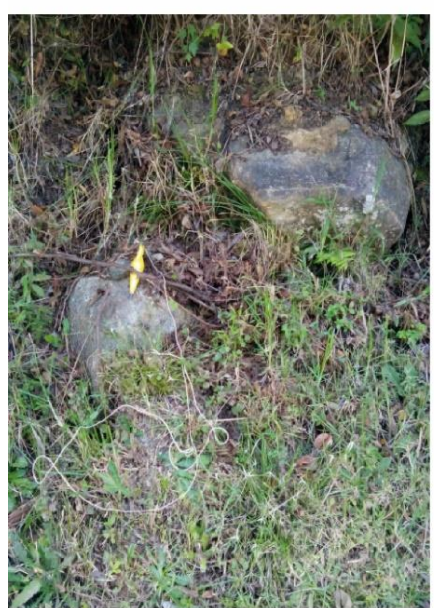

(e)

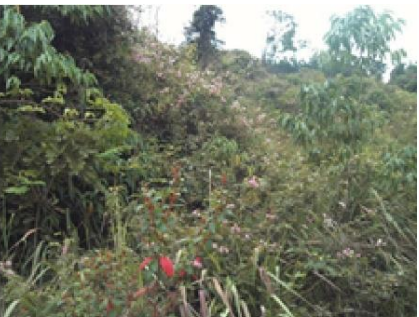

(b)

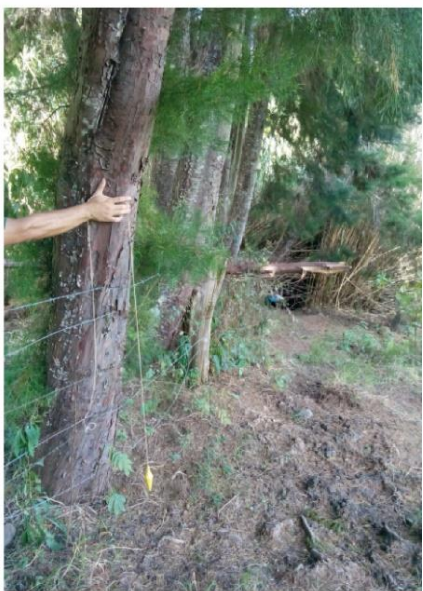

(d)

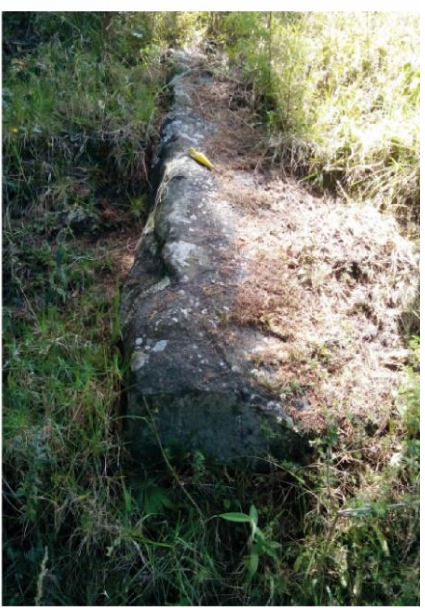

(f)

Figure 2. Some characteristics of the study area: (a) cracks, steps and subsidence on a road at the base of the study parcel; (b) dense native vegetation in the study site, with a mean slope of about $33 \%$; (c) tilted posts in the slope direction; note the yellow plumb indicating the vertical; (d) tilted pine trees; note the yellow plumb; (e) rock boulders cropping out within the study parcel; (f) angular boulder within the study parcel; yellow plumb in $(\mathbf{e}, \mathbf{f})$ is shown for scaling purposes. 
Table 1. Soil physical and chemical properties and instrumentation characteristics of the study plots. Adapted from [15].

\begin{tabular}{|c|c|c|c|c|}
\hline Properties & Site 1 & Site 2 & Soil Parameter & Values \\
\hline Land use & \multicolumn{2}{|c|}{ Marginal Cattle } & sand (\%) & 32 \\
\hline Cartographic Unit (IGAC, 2007) & \multicolumn{2}{|c|}{ Niquia } & silt (\%) & 22 \\
\hline Soil type (SSS, 2014) & \multicolumn{2}{|c|}{ Typic Dystrudept } & clay (\%) & 46 \\
\hline Holdridge Life Zone & \multicolumn{2}{|c|}{ Pre Montane Wet Forest } & Texture & Clay \\
\hline Slope $(\%)$ & 35 & 24 & $\mathrm{pH}$ & 6.0 \\
\hline Geomorphologic position & \multicolumn{2}{|c|}{ Concave Slope } & Organic Mater & 4.16 \\
\hline Drainage & \multicolumn{2}{|c|}{ Well Drained } & Cation Exchange Capacity & 7.3 \\
\hline Root Zone Depth & \multicolumn{2}{|c|}{ Moderately Depth } & Bases Saturation & 52 \\
\hline Stone content $(\%)$ & \multicolumn{2}{|c|}{$15-35 \%$} & bulk density $\left(\mathrm{g} / \mathrm{cm}^{3}\right)$ & 0.8 \\
\hline A horizon thickness $(\mathrm{cm})$ & 55 & 20 & Porosity (\%) & 70 \\
\hline Lysimeter 1 depth $(\mathrm{cm})$ & 50 & 20 & Soil moisture -33 kPa (\%) & 38 \\
\hline Lysimeter 2 depth (cm) & 80 & 60 & Soil moisture $-1500 \mathrm{kPa} \mathrm{( \% )}$ & 26 \\
\hline
\end{tabular}

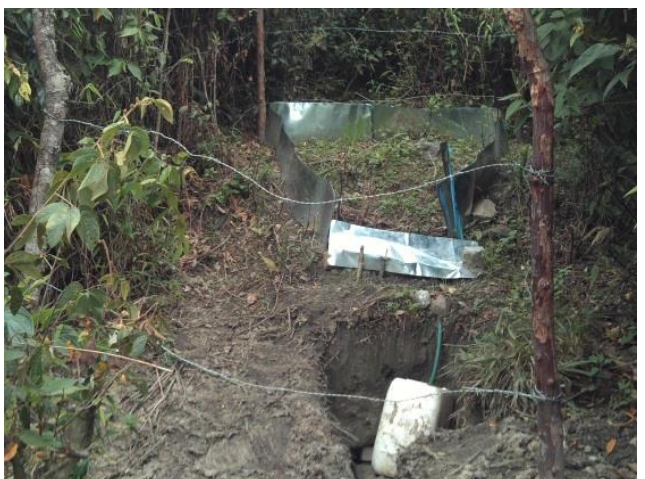

(a)

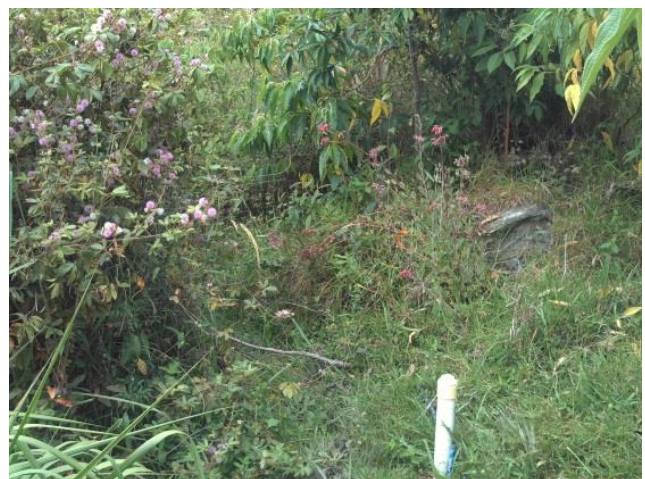

(b)

Figure 3. Some characteristics of the instrumentation: (a) runoff plot; two zero-tension lysimeters were installed at different depths within the plots; and (b) one of the four piezometers installed along the slope.

\section{Results and Discussion}

\subsection{Soil Profile and Properties}

The soil type in the study site is classified as a Typic Dystrudept. It exhibits cambic and redox features in the B horizon, associated with changes in color $(2.5 \mathrm{Y} 4 / 3)$ and frequent to abundant grey spots. Redoximorphic features include nodules of Fe and Mn oxihydroxides, Fe-depletion hypocoatings, and Fe-oxihydroxides quasicoatings around pores. A recent study [24] reports typical Fe nodules and halos with strong impregnation in soils that are related to high concentrations of Fe and $\mathrm{Al}$ in anoxic conditions. The lithological discontinuities are related to depositional processes of fine and rocky materials associated to humid conditions and water table dynamics. According to Soil Taxonomy [25], this soil is a clay, has udic soil moisture regimes with low organic matter rich in clays, and subangular rock blocks and heterometric colluvia comprised of boulders and pebbles (amphibolite, gabbro and schist). Hydromorphic pedofeatures in the gleyed horizons (Bwg) include hard and soft iron oxyhidroxide concretions and impregnative Fe coatings along with Fe depleted hypocoatings on pore walls and aggregate surfaces associated with the pore system [26,27]. The cation interchange from seasonal water table fluctuations at depth tends to enhance leaching of cations linked to the alternation of $\mathrm{Fe}(\mathrm{II})-\mathrm{Fe}(\mathrm{III})$ due to the seasonal reduction-oxidation, which may increase acidity at depth. Soil pH is strongly to moderately acid due to the variable amounts of kaolinite and iron oxides. Some studies [28] state that this is common in tropical soils and indicate that acidic weathering and leaching of basic cations are the dominant pedogenic processes. Cation exchange capacities are low, which is consistent with kaolinite abundance and low $\mathrm{pH}$ and base saturation. Soils with high clay content have a greater water holding capacity, and $\mathrm{pH}$ is influenced by natural processes, such as decomposition of 
organic matter and leaching of cations, as well as by human actions [29]. The soil has low organic matter content in the A horizon and decreases with depth, consistent with a depositional setting with high gravitational instability that contributes to low pedogenetic development. The physicochemical properties of this soil are shown in Table 1. According to Highland et al. [30], soils with weathered materials and contrasts in permeability are highly susceptible to landslides, which is the case at our study site. Studies of creep phenomena underline the importance of the nature of granular materials [31]; in our case, the permeability would not be controlled by the bulk porosity, but by the contrast in particle sizes. Thus, when a combination of fine soil matrix and cobbles/boulders is present, preferential flow within the soil profile is favored. This characteristic is quite common in recently deposited soils [32], such as those at our study site.

\subsection{Precipitation Behavior}

Annual precipitation in our study area, where hydrolgical measurements were conducted, was $1853 \mathrm{~mm}$ for 2016, $1976 \mathrm{~mm}$ for 2017, and $651 \mathrm{~mm}$ for the first four months of 2018 (Figure 4). The largest daily precipitation during our study occurred in August 2016 (66 mm), representing nearly $1.5 \%$ of the precipitation for the entire study period. The daily rainfall during the study period (Figure 4a) distributes as follows: $4 \%$ corresponds to precipitation $>30 \mathrm{~mm}, 14 \%$ between 15 and $30 \mathrm{~mm}, 29 \%$ between 5 and $15 \mathrm{~mm}, 29 \%$ between 1 and $5 \mathrm{~mm}$, and $25 \%$ of the daily data corresponds to values $<1 \mathrm{~mm} ; 82 \%$ of the rainfall is lower than $15 \mathrm{~mm}$ per day. Temporal rainfall exhibits bimodal behavior, with two rainy seasons during the year. The rainiest month was March 2017, with almost $300 \mathrm{~mm}$ of rain, $15.2 \%$ of the annual rainfall for that year; the driest month was July 2017, with about $50 \mathrm{~mm}$, representing $2.5 \%$ of the annual rainfall (Figure $4 \mathrm{~b}$ ). Nevertheless, rainfall occurs year-round and is the primary instigator of soil creep.

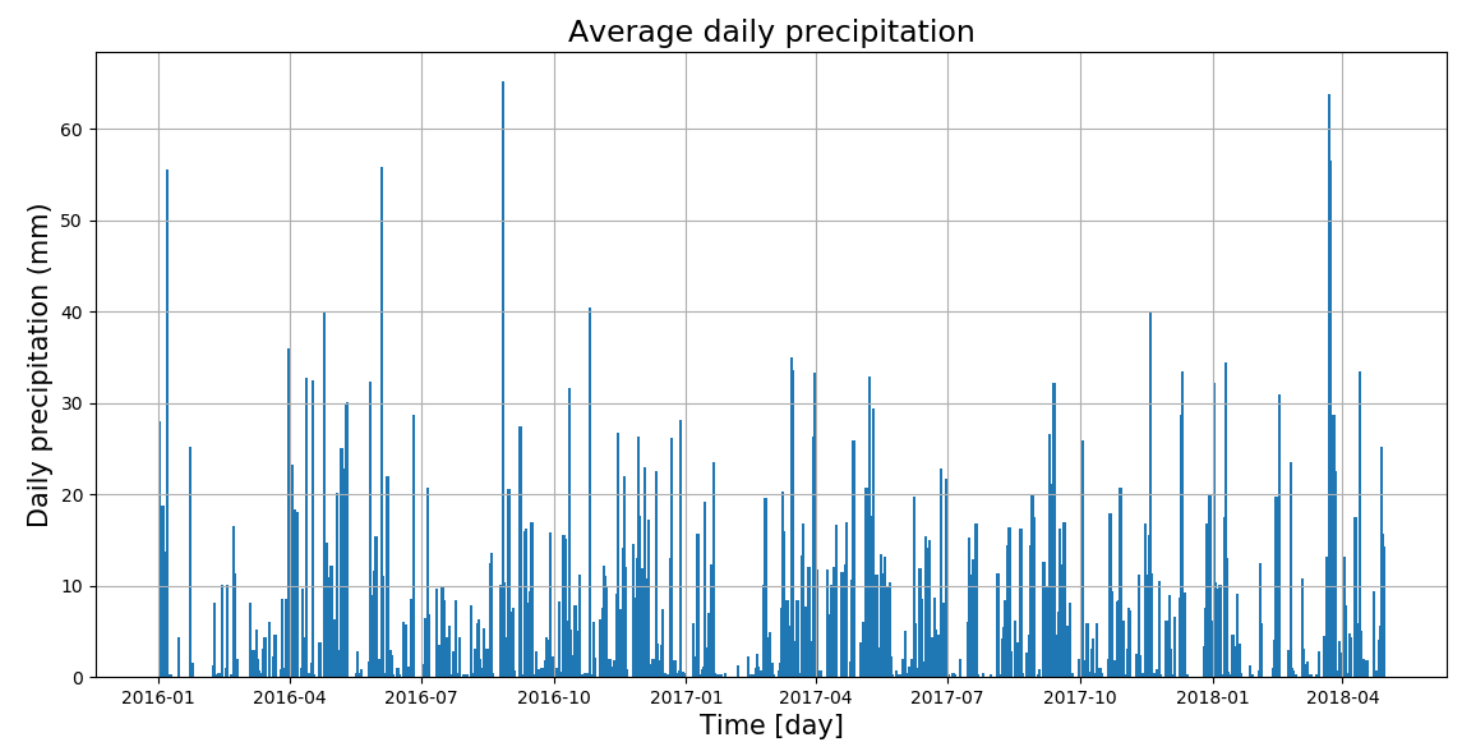

(a)

Figure 4. Cont. 


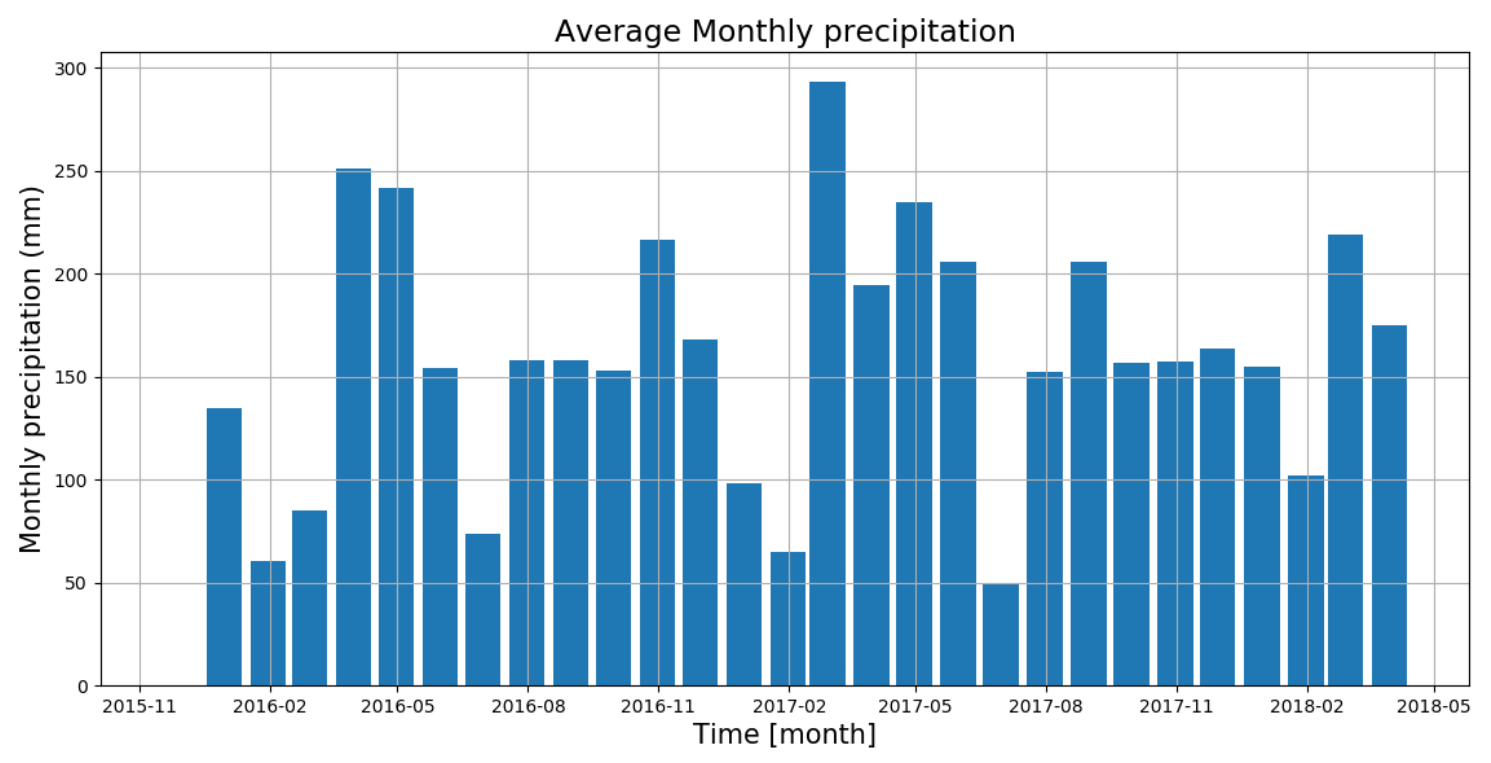

(b)

Figure 4. Precipitation records during the study period. These data were constructed from information from two pluviometric stations within a $2 \mathrm{~km}$ radius of the study site. Raw data were provided by the Early Warning System of Medellín and the Aburrá Valley (SIATA, by its acronym in Spanish). (a) Daily precipitation; (b) monthly precipitation.

\subsection{Runoff Behavior}

The mean surface runoff during the study period ranged between $4 \%$ and $11 \%$ of the total rainfall fluctuating between 0.01 to $15 \mathrm{~mm}$ for rainfall episode; runoff rates vary little with time (Figure 5). The highest runoff values coincide with wet antecedent soil conditions. During rainfall events, low runoff values can be explained by the high infiltration capacity of the soil. Runoff values under tropical dry forest cover in Mexico are $<9.8 \%$, and total rainfall was not significantly correlated with total runoff; however, antecedent rainfall influences runoff generation during extreme events [33]. In the Mediterranean, runoff values relative to total rainfall in pastures ranged between 1 and $2.25 \%$ in rocky soils [34,35]. In a study by Patin et al. [36], values of accumulated runoff fluctuate between 3.3 and $125.9 \mathrm{~mm}$. Field measurements of infiltration at the plot-scale under natural rainfall often exhibit a dependency upon rainfall intensity. Liu et al. [37] reported percentages of rainfall that became runoff as $12.5 \%, 7.6 \%, 8.4 \%$, and $5.6 \%$, for bare soil plots, litter plots, undergrowth plots, and litter plus undergrowth plots, respectively. These results are consistent with those reported in our study. Various studies note the greater importance of soil cover and land use compared to soil type on runoff generation. In our study, the stony character, porosity, and antecedent moisture conditions of soils are more important than the cover type. Our runoff values remained relatively constant and periodically low values are associated with soil physical properties (Table 1). Thus, one might conclude that the high soil infiltration contributes to high subsurface water fluxes, increasing the likelihood of landslide episodes and intensifying soil creep processes, especially in prolonged rainfall periods. 


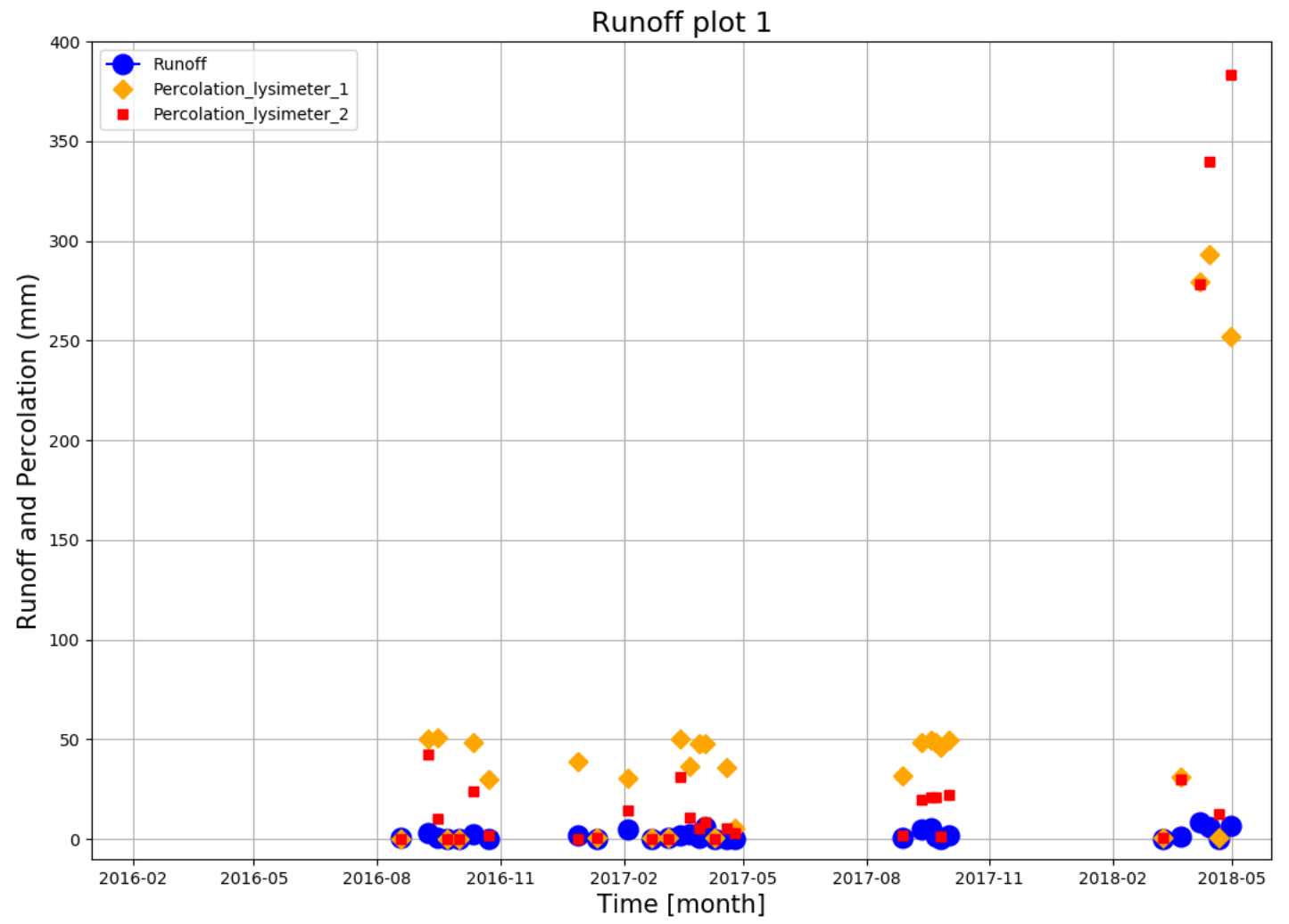

(a)

Runoff plot 2

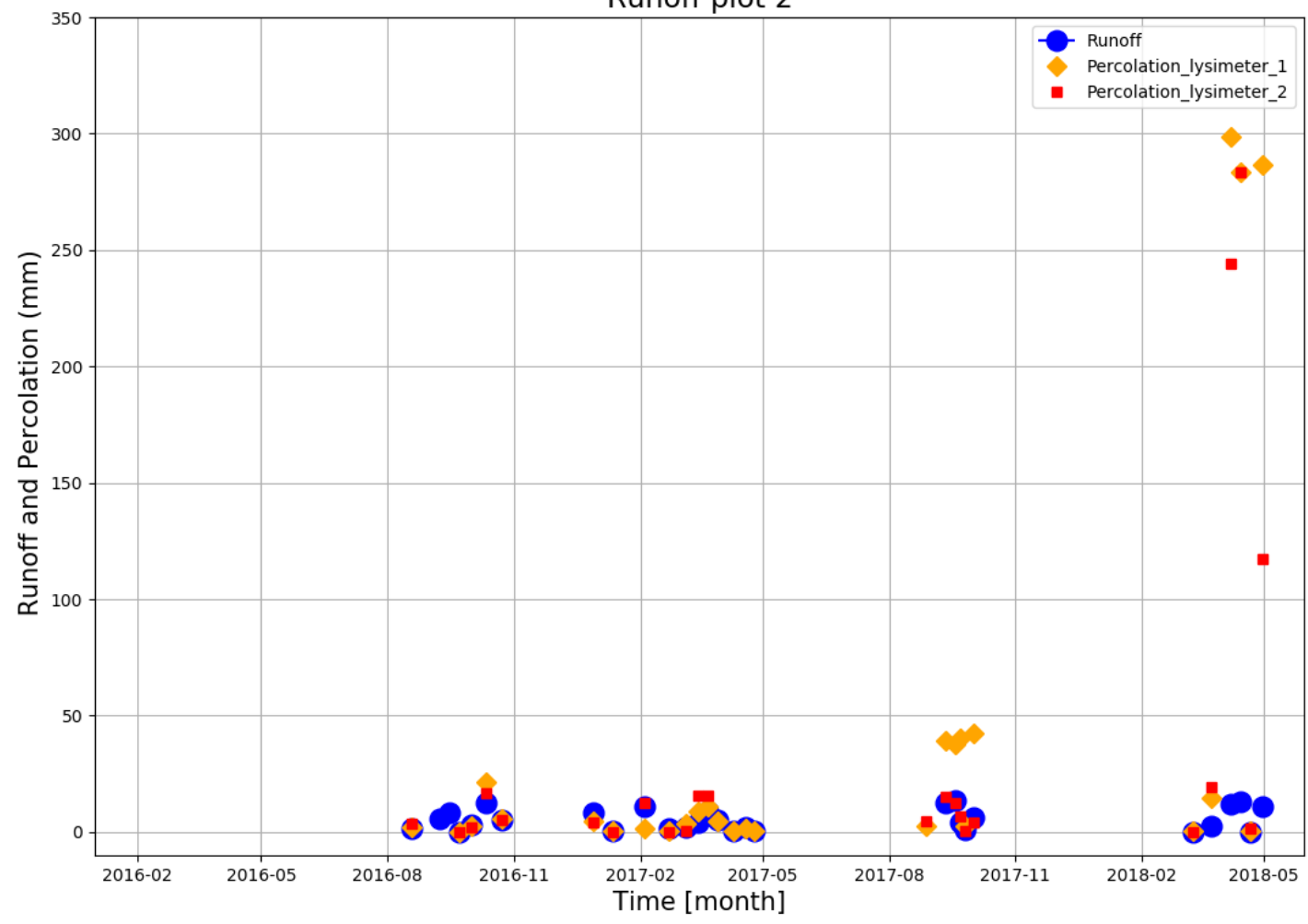

(b)

Figure 5. Runoff and lysimeter measurements in the two plots (plot locations are in Figure 1). (a) Runoff plot 1 ; (b) Runoff plot 2. 


\subsection{Soil Percolation Behavior}

During four time intervals within our study period, we measured percolation captured in zero-tension lysimeters at two different levels in the soil mass (Figure 5). The percolation within the A horizons (20 to $50 \mathrm{~cm}$ depth) fluctuates between $0.17 \mathrm{~mm}$ to $298.5 \mathrm{~mm}$; and within the B horizons (60 to $80 \mathrm{~cm}$ depth) it varies between $0.08 \mathrm{~mm}$ to $283.3 \mathrm{~mm}$. The total percolation water fluctuates between $89 \%$ and $96 \%$ of the total rainfall. Supported by the soil survey data, it appears that preferential flow occurs as bypass flow through macropores, root channels and cracks, and the combination of the matrix and blocks within the soil favors subsurface flows. Table 2 shows the behavior of infiltration, percolation, runoff, and rainfall for the experimental plots during the periods when measurements were taken. Our observed data shows that 15 to $33 \%$ of the total rainfall recharges the soil water table via drainage water; also, the lysimeter records show that between 45 to $81 \%$ of the total rainfall moves downslope as subsurface flow (Figure 5). These processes are favored by the soil physical properties and high stone content. Surveys such as those conducted by Gómez et al. [38] show that 50\% of the spatial variation in plot infiltration and runoff can be explained by spatial variability of saturated hydraulic conductivity; the remaining $50 \%$ is explained by variability in rainfall and measurement errors. For storms in which rainfall infiltration is high, sometimes the percolation is reduced by excessive soil water recharge [36]. The periodically shallow water table (see next section) and the commonly high degree of saturation favor wetland conditions at the study site; infiltration values tend to be higher than those associated to other soil uses.

Table 2. Water flux components during only the periods when hydrological measurements were collected. Units are in $\mathrm{mm}$.

\begin{tabular}{cccccc}
\hline Site & Rainfall & Runoff & Infiltration & Lysimetric Percolation & Drainage Water \\
\hline Plot 1 & \multirow{2}{*}{1693} & 70 & 1623 & 1374 & 249 \\
Plot 2 & & 178 & 1515 & 953 & 562 \\
\hline
\end{tabular}

In Figure 5, we can see that for both sites where lysimeters were installed, relatively high volumes of lysimeter water were collected around March-April 2018. It is clear from Figure 4 that this period is not especially rainy compared with the rest of the study period. However, if we account for rainfall between consecutive measurements, it is clear that, on average, during the period of March-April 2018, it rained $\sim 40 \%$ more than during the sampling period of September-October 2016. This apparent anomaly is explained by the rainfall in short-term intervals when periodic measurements were taken, even though monthly precipitation does not differ much between the entire March-April 2018 and September-October 2016 periods (Figure 4b).

The previous results indicate that most of the precipitation water infiltrates, and there is a significant lateral subsurface flow component within the soil mass. This is consistent with the clayey nature of the soil, its high heterogeneity, and the significant stone content; the flow paths should be irregular and locally discontinuous, with preferential channels developed through cobbles and boulders; it is very likely that these lateral fluxes within the soil occur in a zone of perched groundwater. Although there are significant differences between the soils assessed in this study and those addressed by Ali et al. [39], the complexity of the flow paths, the discontinuous storage, and the nature of the subsurface flow should be similar to those within the soils described by these authors. The importance of these fluxes in our study area is evidenced by the presence of gleyed horizons, as described in Section 3.1. Given the relatively steep slope ( 33\%) of our study site, the downhill subsurface flow should be very active, concentrated in the shallowest levels of the subsurface (within the first meter), and therefore, contributing significantly to soil creep. 


\subsection{Piezometric Levels}

Water table fluctuations due to precipitation are an obvious yet informative process that can be translated to the subsurface hydraulic characteristics of porous media [40-42]. Measurements of piezometric levels during the study period suggest a direct relationship between precipitation and the water table within the soil (Figure 6). The most interesting aspect of these responses is the high water table level even in dry periods (e.g., February-March, 2017 and 2018), suggesting that the soil is recharged mainly by subsurface flow from the upper part of the slope. In rainy periods, the water table remains near the surface, but in the long dry periods, it fluctuates between depths of 9 to $110 \mathrm{~cm}$. These results are similar to the piezometric depths reported for humid mountain areas $[40,43]$. Therefore, we infer that the water table remains close to the surface all year round, and deepens to about $1 \mathrm{~m}$ during the dry periods (Figure 6).

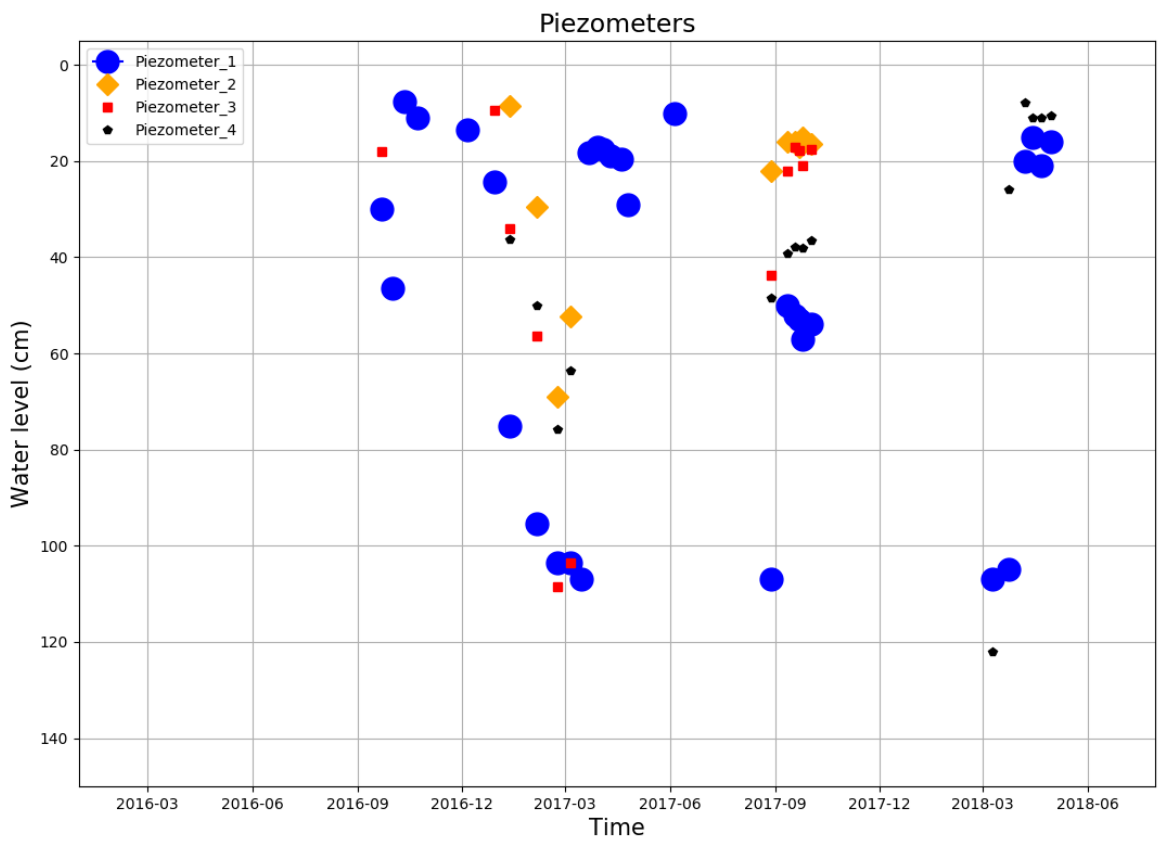

Figure 6. Piezometric levels measured within the study site, represented as cm below ground level. Piezometers are numbered from 1 to 4 , from top to bottom of the study site (see Figure 1 for piezometer locations).

Our measurements of water table level are consistent with discussions in the previous section. The year-round quasi-stable shallow water table reinforces the evidence of preferential subsurface flow within the shallowest levels of the subsurface; this is most likely a zone of perched groundwater, whose existence is facilitated by the heteogeneity of the soil, its clayey nature, and the superposition of different debris flows, which form lateral discontinuities within the soil profile. Several times during the year, saturation occurs, which clearly favors the slow downhill movement of soil.

\subsection{Electrical Resisitivity Tomography (ERT)}

Results of the processing of dipole-dipole data along the profile (green line, T1 in Figure 1) are presented in Figures 7 and 8. Figure 7 shows the field data of apparent resistivity (top panel), the predicted data for the model of minimum misfit (middle panel), and the resulting model or tomographic image of electrical resistivity (bottom panel). Figure 8 illustrates the tomographic model, accounting for the topography. It is clear that low resistivity materials $(<70 \Omega \mathrm{m})$ concentrate in the shallowest 3 to $5 \mathrm{~m}$ of the section, with some localized larger values (of the order of $1000-1500 \Omega \mathrm{m}$ ) in the upper portion of the hillslope (Figure 8, top-left). This particular high resistivity feature might correspond to the presence of occasional boulders in the shallowest layers. At subsequent deeper 
levels, a strong gradient towards greater values of resistivity is observed, reaching values of the order of several thousand $\Omega \mathrm{m}$. These values are expected as deeper materials are more consolidated, but this resistivity distribution might also indicate that meteoric water is basically concentrated in the uppermost levels, and the lower sampled levels are dryer. This result is consistent with the shallow and steady-state subsurface flow and water table. In any case, the overall structure revealed by this tomographic image suggests the presence of a strong discontinuity between $3 \mathrm{~m}$ and $6 \mathrm{~m}$ below the surface, that might play a key role in the instability of the area.

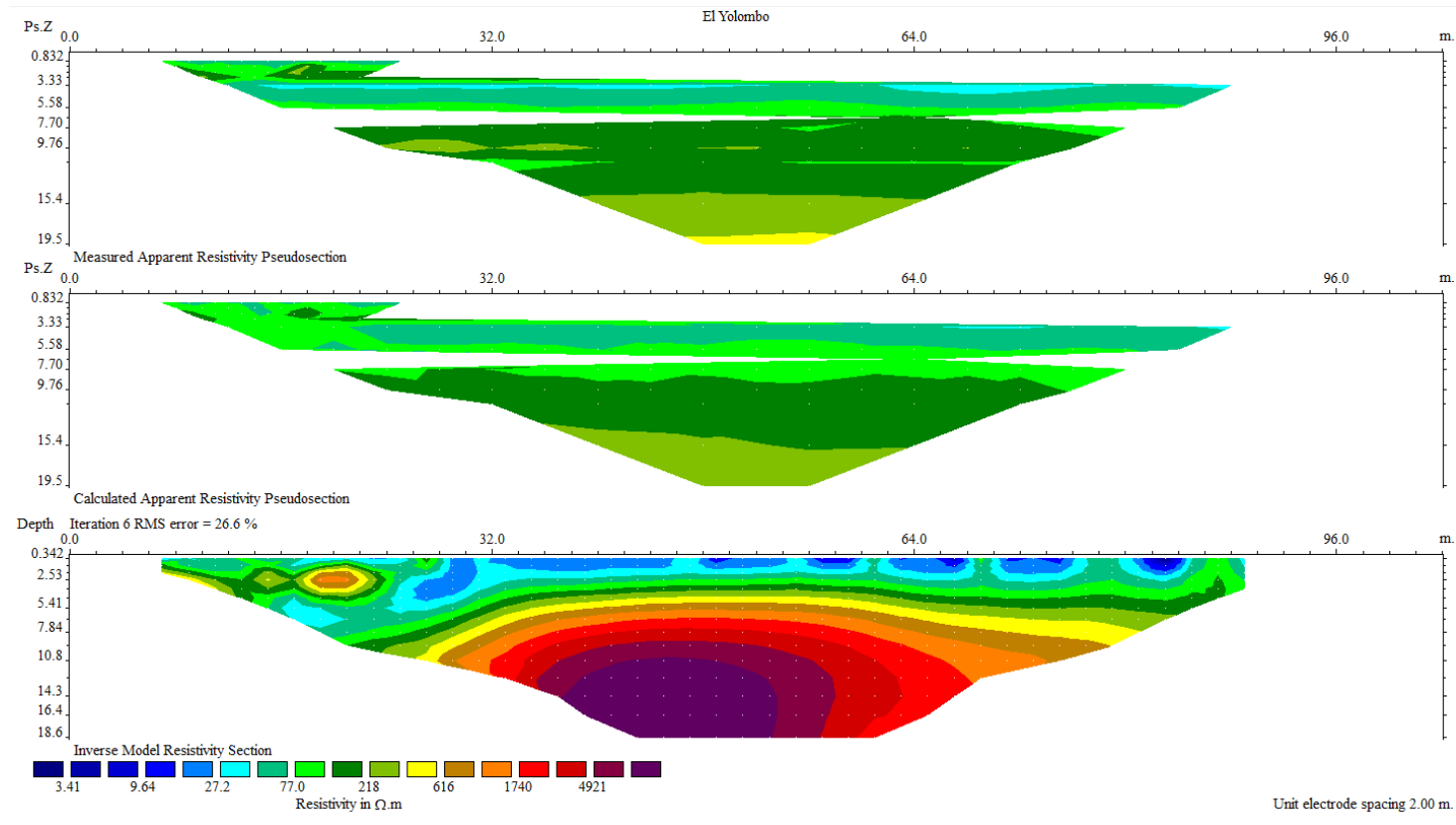

Figure 7. Construction of the tomographic section along the maximum slope of the study site (green line in Figure 1). Top panel shows the apparent resistivity pseudosection with the data measured in the field; middle panel shows the pseudosection with the predicted apparent resistivities that would correspond to the preferred model obtained from inversion; bottom panel shows the result of the inversion, the resistivity model that best fits the data. The RMS of the residuals, given in percentage, is 26.6 .

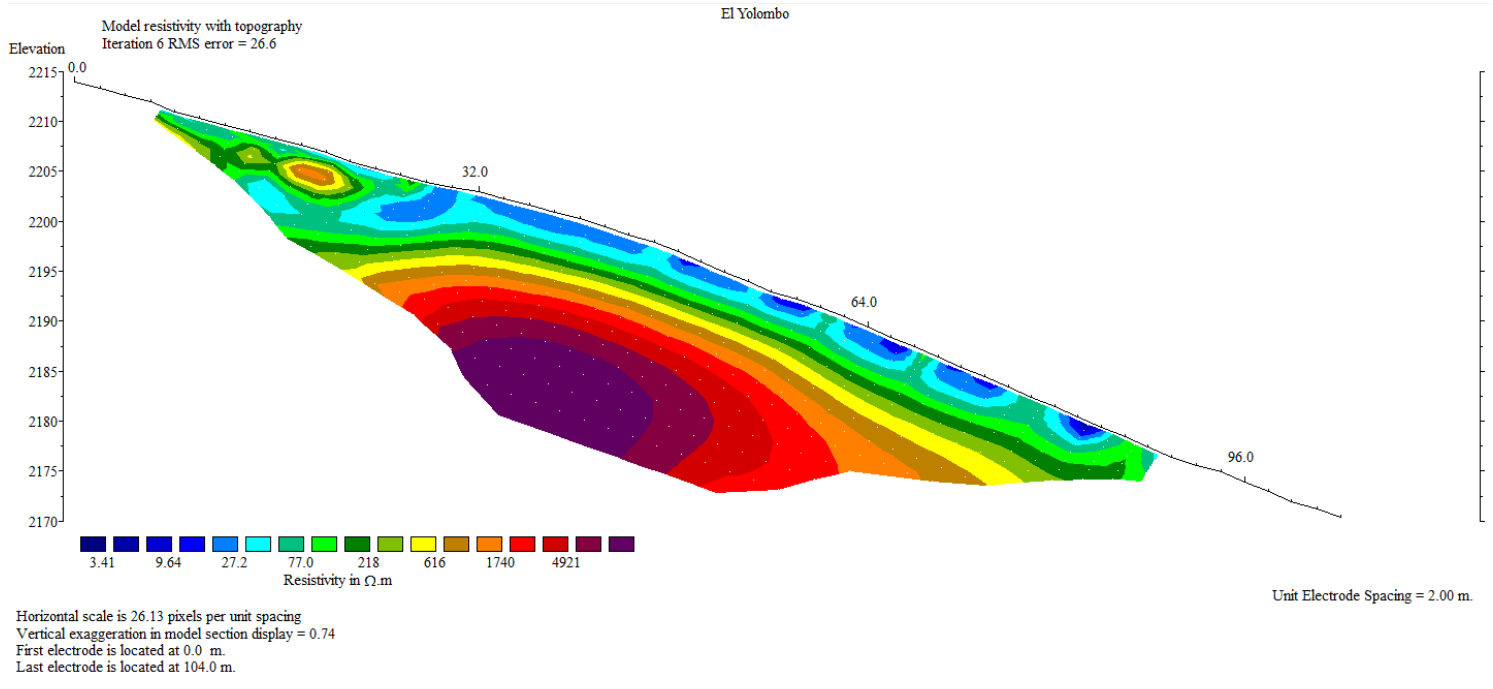

Figure 8. Resistivity model illustrated in Figure 7, but with the topography correction. Cross-section location is depicted by a green line in Figure 1 (T1). 


\subsection{Vertical Electrical Soundings (VES)}

The resulting 1D models of the three VES at three locations on the study area (L1, L2 and L3 in Figure 1) are shown in Figure 9. After an exploration of the solution space for all cases, three-layer models were selected as the best fit to field data. Thus, for each location, we retained the number of layers and their respective thickness as constant parameters during the inversion. From the inversion of data collected along the three lines and during three different times in 2016, a common pattern of a low resistivity layer sandwiched between two higher resistivity layers is apparent. The only exception is the results of 12 April 2016, at L2 (Figure 9, text in red). The deepest resistivity contrast may correspond to the discontinuity detected in the ERT image (Figure 8, Section 3.6). It is important to note that the deepest layer in section L3 has relatively low resistivity values compared to L1 and L2, suggesting that at the base of our study parcel (L3), materials at depths of between 3 to $7 \mathrm{~m}$ below the surface are wetter than materials at those same depths at upper locations along the slope (L1 and L2); this accumulation of water at the base is consistent with the high percolation and subsurface downhill flow; it is also likely that at the location of L3, given the relative decrease in slope, the vertical water fluxes are more favored than at the other locations upslope, and so the deepest sampled subsurface layers should receive water from both infiltration and subsurface flow emanating from higher elevations. Even though the resistivity contrasts are well defined at the three locations of the VES, at least for the three-month period represented here, there is not a notable temporal change in the geo-electrical structure of the soil.

L1

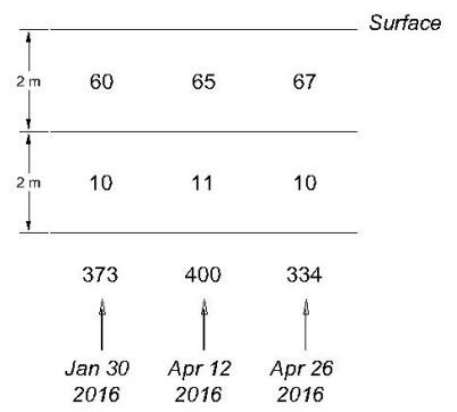

L2

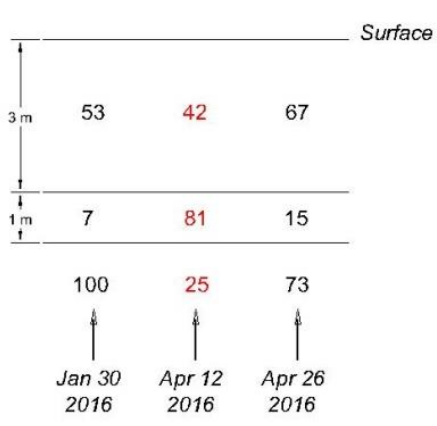

L3

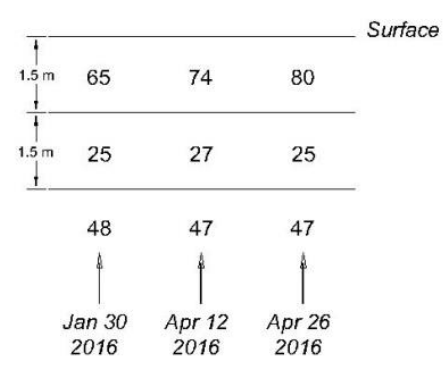

Figure 9. Summary of the three-layer resistivity models derived from the VES conducted at locations L1 (left), L2 (middle) and L3 (right) on three different dates (indicated at the bottom) in 2016. See Figure 1 for experimental locations. The numbers correspond to electrical resistivity in $\Omega \mathrm{m}$. Resistivities obtained from measurements on 12 April 2016, are in red because they do not follow the general pattern of variation of resistivity with depth, which is shown by the other eight models.

\subsection{Multichannel Analysis of Surface Waves (MASW)}

Using active seismic records collected by 24 geophones, dispersion curves of Rayleigh waves were constructed, which were inverted to find a plausible shear wave velocity (Vs) profile. Quantification of Vs can be used as a proxy for soil rigidity. After exploring the solution space, and to avoid over-parameterization of the seismic structure, we chose a structure of two layers to fit the dispersion curves. In this case, the depth of the main interface was left as a free parameter. Figure 10 shows the best fitting layer models for Vs at the three chosen locations (L1, L2 and L3, Figure 1) at three different times during the first half of 2017. The different configurations reveal the existence of at least one significant contrast at a level similar to that obtained with the electrical methods, with only one exception, the great depth of the interface at L1 for 6 February 2017 (Figure 10). The main interface depth is close to the values suggested by the ERT and the VES for a major discontinuity, between 3 to $6 \mathrm{~m}$ below the surface. 


\section{L1}

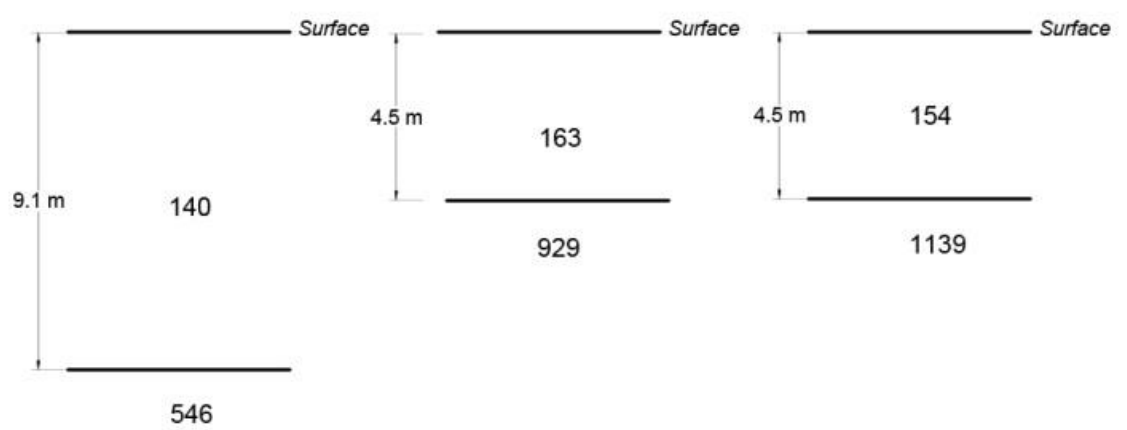

L2

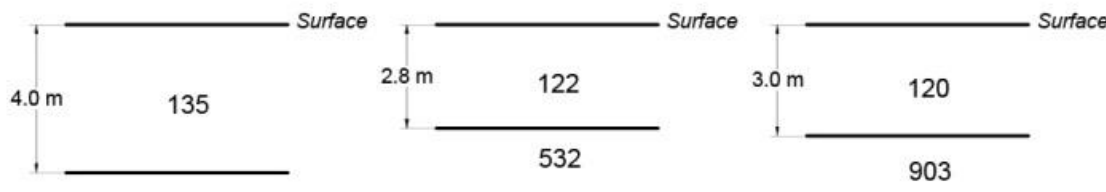

556

L3
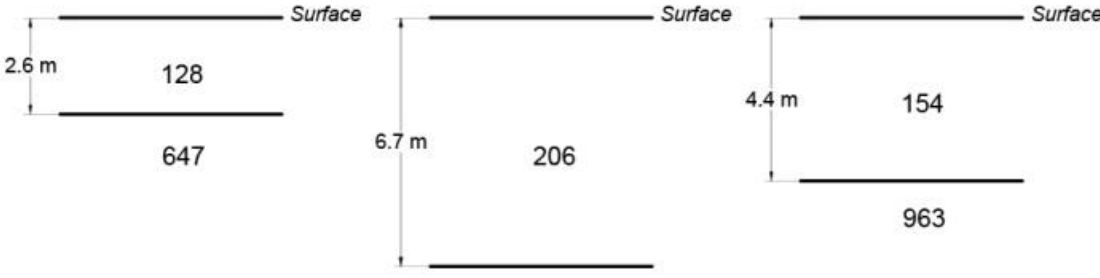

963

671
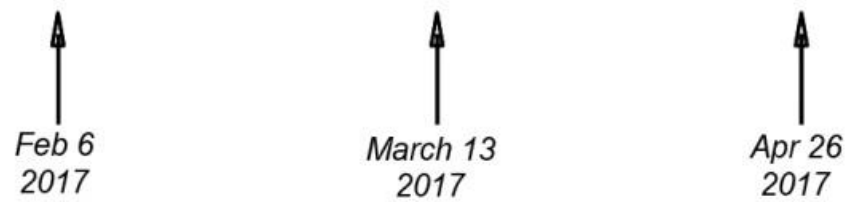

Figure 10. Summary of the two-layer shear seismic wave velocity (Vs) models derived from the MASW surveys conducted at locations L1 (top), L2 (middle) and L3 (bottom), on three different dates in 2017 (indicated at the bottom). See Figure 1 for experimental locations. The numbers correspond to seismic wave speed in $\mathrm{m} / \mathrm{s}$.

To check for the plausibility of the results of the MASW surveys, we collected several soil samples in a Shelby tube for unconfined compression tests. Samples were taken at the $1.20 \mathrm{~m}$ depth at a mid-point between L1 and L2, and at the $0.8 \mathrm{~m}$ depth at a mid-point between L2 and L3 (Figure 1). The values of Young's modulus obtained from laboratory tests were 107.3 and $99.5 \mathrm{MPa}$, respectively. If we consider Poisson's ratios for clayey soils between 0.4 and 0.5 [44], we would obtain shear moduli between $\sim 33$ and $39 \mathrm{MPa}$, which corresponds to a range of Vs between $\sim 114$ and $160 \mathrm{~m} / \mathrm{s}$. These results are similar to the speeds that we get for the shallowest layer in our inversions (Figure 10).

For the three locations of seismic surveys, we notice a slight increase in the rigidity contrast between the measurements of March and April 2017. Since March 2017 was the rainiest month during the sampling period (Figure $4 \mathrm{~b}$ ), we would expect a decrease in the rigidity contrast as a result of more water in the soil mass. Our finding of a relatively stable contrast is consistent with a relatively high and permanent degree of saturation in the soil (first 1-2 m), the high infiltration and subsurface flow concentrated in the upper few meters of the soil profile. It is highly possible that most of the water does not cross the hydraulic discontinuity due to the high boulder content and the more consolidated 
nature of the materials at the bottom (associated with old debris flow deposit), and that a perched water table is generated.

\section{Summary and Conclusions}

Our preliminary results demonstrate the feasibility of using measured hydrological fluxes to better understand the water behavior inside unstable hillslopes that experience slow soil movement (e.g., creep). Additionally, geophysical surveys can be used to resolve the structure of the shallow subsurface, thus elucidating the properties of the soil and the nature of the deposits, so that they can be related to water behavior.

In general, the hydrological measurements show that the soils at the study site tend to have high soil moisture conditions (periodically saturated), and rarely reach low moisture values. The high values of infiltration, percolation (subsurface flow and drainage water), and the shallow water table depth, explain the low variation in soil moisture content and the high water drainage and subsurface flow values (Table 2). These findings suggest that the replenishment of water in these soils occurs via drainage and subsurface flow from the upslope area, which supports active soil creep. The infiltration and percolation is very high, and therefore, its influence on water flux is significant, especially at the hillslope scale. The water table is usually shallow (within the first meter of soil), regardless of relatively dry periods; this behavior of the water table is favored by high infiltration and percolation. The land use at this locality also favors subsurface water fluxes, resulting in a decrease of runoff and increased subsurface flow, water drainage, and soil saturation. The soil matrix is rich in rock fragments and supports preferential flow; the presence of a shallow water table favors wetland soils, confirmed by the presence of gleyed patterns in the soil profile. Despite the high clay content, the general hydrological properties facilitate subsurface flow along the slope.

The geophysical surveys allowed a deeper sampling of the physical properties of soil and deposits; however, the degree of detail that their interpretation can resolve is somewhat limited. With the available geophysical data, no variation of the subsurface structure with time is apparent; thus, it seems that, regardless of the existence of wet and dry periods, subsurface physical properties do not significantly change. This result is consistent with the fact that the soil is nearly saturated almost year-round, and that a considerable percentage of water is moving downhill as subsurface flow. However, longer and more regular sampling is necessary to confirm this hypothesis. Of particular importance is the fact that electrical resistivities in the deepest resolved layer are relatively low at the base of the site (L3, Figure 1), where the slopes are gentler than at the other locations uphill (L1 and L2, Figure 1). These data might indicate a greater content of water at the base of the study site, which is also consistent with the high infiltration, percolation, and subsurface downhill flow accumulation. The MASW seismic surveys reveal a relatively rigid bottom layer, even after very wet periods, which indicates the presence of perched water storage in the shallowest subsurface layers. In general, the results show a major discontinuity at $\sim 4-6 \mathrm{~m}$ below the surface that represents a significant contrast in electrical resistivity and shear seismic wave speed (rigidity). This discontinuity is likely related to contact between two debris flows with significant differences in age and compaction. Such contact can be a major interface that could facilitate downslope sliding. However, it seems like the persistent slow creep is facilitated by the high subsurface flow, and we speculate that it is fastest within the shallowest first meter, which remains highly saturated, and where downhill fluxes should be most active.

Author Contributions: Conceptualization, experiment designs, writing-review and editing were conducted by J.C.L.-U., G.M. and R.C.S.; J.C.L.-U and A.P.-P. performed the hydrological measurements and data processing; L.A.-M. made the initial characterization of the study area and conducted the VES; M.S. conducted the MASW measurements and analysis; L.F.R.-H. conducted the ERT.

Funding: This research received no external funding.

Acknowledgments: We would like to thank several generations of students of the undergraduate courses of Geotechnical Mapping for identifying the study site as a critical spot for detailed studies; we especially thank 
the course instructor, Maria I. Mesa, for sharing the observations of several years of teaching in the area. We are thankful to L. Sabina Vahos, Jana Smolikova, and Santiago Vélez for their help and participation during the initiation of our observations. Jorge A. Alzate and Joshua M. Quiroz are acknowledged for the piezometer, runoff and lysimeter data collection during 2016 and 2017. We also thank Santiago Hincapié, José D. Henao, W. Camilo Fuertes, and students of the undergraduate course of General Geophysics for their help during the geophysical surveys. Guillermo Mesa and the GITA research group are acknowledged for the development of geo-electrical equipment. The firm "AIM Ingenieros" helped us with the seismic equipment and their lab facilities; special thanks to engineer Jorge A. Hurtado. We also thank the Early Warning System of Medellín and the Aburrá Valley (SIATA, by its acronym in Spanish) for providing us with the precipitation time series.

Conflicts of Interest: The authors declare no conflicts of interest.

\section{References}

1. Schuster, R.L.; Highland, L.M. Socioeconomic and Environmental Impacts of Landslides on the Western Hermisphere; USGS Open-File Report 2001-276; USGS: Reston, VA, USA, 2001; 46p.

2. Aristizábal, E.; Yokota, S. Geomorfología aplicada a la ocurrencia de deslizamientos en el Valle de Aburrá. Dyna 2006, 149, 5-16.

3. Aristizábal, E.; Gómez, J. Inventario de emergencias y desastres en el Valle de Aburrá originados por fenómenos naturales y antrópicos en el período 1880-2007. Gest Ambient. 2007, 10, 17-30.

4. Garland, G.G.; Olivier, M.J. Predicting landslides from rainfall in a humid, sub-tropical región. Geomorphology 1993, 8, 165-173. [CrossRef]

5. Aristizábal, E.; González, T.; Montoya, J.D.; Vélez, J.I.; Martínez, H.; Guerra, A. Análisis de umbrales empíricos de lluvia para el pronóstico de movimientos en masa en el Valle de Aburrá, Colombia. Rev. EIA 2011, 15, 95-111.

6. Aristizábal, E.; Martínez-Carvajal, H.; García-Aristizábal, E. Modelling shallow landslides triggered by rainfall in tropical and mountainous basins. In Advancing Culture of Lining with Landslides; Mikos, M., Casagli, N., Yin, Y., Sassa, K., Eds.; WLF, Springer: Cham, Switzerland, 2017; pp. 207-212.

7. Larsen, M.C.; Simon, A. A rainfall intensity-duration threshold for landslides in a humid-tropical environment, Puerto Rico. Geogr. Ann. Ser. A Phys. Geogr. 2017, 75, 13-23. [CrossRef]

8. Moreno, H.A.; Vélez, M.V.; Montoya, J.D.; Rhenals, R.L. La lluvia y los deslizamientos de tierra en Antioquia: Análisis de su ocurrencia en las escalas interanual, intra-anual y diaria. Rev. EIA 2006, 5, 59-69.

9. Echeverri, O.; Valencia, Y. Análisis de los deslizamientos en la cuenca de la quebrada La Iguaná de la ciudad de Medellín a partir de la interacción lluvia-pendiente-formación geológica. Dyna 2004, 142, $33-45$.

10. Aristizábal, E.; Roser, B.; Yokota, S. Tropical chemical weathering of hillslope deposits and bedrock source in the Aburrá Valley, northern Colombian Andes. Eng. Geol. 2005, 81, 389-406. [CrossRef]

11. Shrestha, H.K.; Yatabe, R.; Bhandary, N.P. Use of groundwater flow model in the analysis of a creeping lanslide in western Japan. Episodes 2006, 29, 20-25.

12. Lindenmaier, F.; Zehe, E.; Wienhöfer, J.; Ihringer, J. Hydrological patterns and processes of a deep seated creeping slope at Ebnit, Vorarlberg. In Proceedings of the INTERPRAEVENT 2008, Dornbirn, Vorarlberg, Austria, 26-30 May 2008; Volume 2, pp. 183-194.

13. Bogaard, T.A.; Greco, R. Landslide hydrology: From hydrology to pore pressure. WIREs Water 2016, 3, 439-459. [CrossRef]

14. Loaiza-Usuga, J.C.; Pauwels, V.R.N. Calibration and multiple data set-based validation of a land surface model in a mountainous Mediterranean study area. J. Hydrol. 2008, 356, 223-233. [CrossRef]

15. IGAC. Estudio General de Suelos y Zonificación de Tierras, Departamento de Antioquia; Instituto Geográfico Agustín Codazzi, IGAC: Bogota, Colombia, 2007. (In Spanish)

16. Bond, W.J. Soil Physical Methods for Estimating Recharge-Part 3: Basics of Recharge and Discharge Series; CSIRO Publishing: Clayton, Australia, 2008; pp. 1-16. ISBN 9780643105355.

17. Loke, M.H. Electrical Imaging Surveys for Environmental and Engineering Studies. A Practical Guide to 2-D and 3-D Surveys; GEOTOMO SOFTWARE SDN BHD: Penang, Malaysia, 2000; 67p.

18. Loke, M.H.; Acworth, I.; Dahlin, T. A comparison of smooth and blocky inversion methods in $2 \mathrm{D}$ electrical imaging surveys. Explor. Geophys. 2003, 34, 182-187. [CrossRef]

19. Loke, M.H. RES2DINV: Rapid 2-D Resistivity and IP Inversion Using the Least-Squares Method; Geotomo Software: Penang, Malaysia, 2003. 
20. Burger, R.; Sheehan, A.F.; Jones, C.H. Introduction to Applied Geophysics: Exploring the Shallow Subsurface, 2nd ed.; W.W. Norton \& Company, Inc.: New York, NY, USA, 2006; pp. 1-554. ISBN 0-393-92637-0.

21. Park, C.B.; Miller, R.D.; Xia, J. Multichannel analysis of surface waves. Geophysics 1999, 64, 800-808. [CrossRef]

22. ELIOSOFT, Geophysical Software and Services. winMASW2018, User Manual; ELIOSOFT: Palmanova, Italy, 2018; 248p.

23. Dal Moro, G.; Pipan, M.; Gabrielli, P. Rayleigh wave dispersion curve inversion via genetic algorithms and marginal posterior probability density estimation. J. Appl. Geophys. 2006, 61, 39-55. [CrossRef]

24. Loaiza-Usuga, J.C.; Sánchez, J.A.; Rubiano, Y.; Poch, R.M. Late Pleistocene polygenetic Andean wetland soils. Geo. Res. J. 2017, 14, 20-35. [CrossRef]

25. Soil Science Division Staff (SSDS). Soil Survey Manual; Ditzler, C., Scheffe, K., Monger, H.C., Eds.; United States Department of Agriculture (USDA), Government Printing Office: Washington, DC, USA, 2017; pp. 1-585.

26. Hobson, W.A.; Dahlgren, R.A. Wetland soils of basins and depressions: Case studies of vernal pools. In Wetland Soils, Genesis, Hydrology, Landscapes and Classification; Richardson, J.L., Vepraskas, M.J., Eds.; Lewis Publishers: Boca Ratón, FL, USA, 2001; pp. 267-282. ISBN 13.

27. Boixadera, J.; Poch, R.M.; García González, M.T.; Vizcayno, C. Hydromorphic and clay-related processes in soils from the Llanos de Moxos (northern Bolivia). Catena 2003, 54, 403-424. [CrossRef]

28. Khawmee, K.; Suddhiprakarn, A.; Kheoruenromne, I.; Singh, B. Surface charge properties of kaolinite from Thai soils. Geoderma 2013, 192, 120-131. [CrossRef]

29. CUCE. Cation Exchange Capacity (CEC). Agronomy Fact Sheet Series \# 22; Department of Crop and Soil Sciences, College of Agriculture and Life Sciences, Cooperative Extension (CUCE), Cornell University: Ithaca, NY, USA, 2007; 2p.

30. Highland, L.M.; Bobrowsky, P. The Landslide Handbook-A Guide to Understanding Landslides; USGS Circular 1325; USGS: Reston, VA, USA, 2008; 129p.

31. Bowman, E.T.; Soga, K. Creep, ageing and microstructural change in dense granular materials. Soils Found. 2003, 43, 107-117. [CrossRef]

32. Schmertmann, J.H. The mechanical aging of soils. J. Geotech. Eng. 1991, 117, 1288-1330. [CrossRef]

33. Maass, M.; Ahedo-Hernández, R.; Araiza, S.; Verduzco, A.; Martínez-Yrízar, A.; Jaramillo, V.J.; Parker, G.; Pascual, F.; García-Méndez, G.; Sarukhán, J. Long-term (33 years) rainfall and runoff dynamics in a tropical dry forest ecosystem in western Mexico: Management implications under extreme hydrometeorological events. For. Ecol. Manag. 2018, 426, 7-17. [CrossRef]

34. Verdú, J.M.; Batalla, R.J.; Poch, R.M. Dinámica erosiva y aplicabilidad de modelos físicos de erosión en una cuenca de montaña mediterránea (Ribera Salada, Cuenca del Segre, Lleida, España). Pirineos 2000, 155, 37-57. [CrossRef]

35. Orozco, M.; Poch, R.M.; Batalla, R.J.; Balasch, J.C. Hydrochemical budget of a Mediterranean mountain basin in relation to land use (The Ribera Salada, Catalan Pre-Pyrenees, NE Spain). Z. Geomorphol. 2006, 50, 77-94. [CrossRef]

36. Patin, J.; Mouche, E.; Ribolzi, O.; Chaplot, V.; Sengtahevanghoung, O.; Latsachak, K.O.; Soulileuth, B.; Valentin, C. Analysis of runoff production at the plot scale during a long-term survey of a small agricultural catchment in Lao PDR. J. Hydrol. 2012, 426-427, 79-92. [CrossRef]

37. Liu, W.; Luo, Q.; Lu, H.; Wu, J.; Duan, W. The effect of litter layer on controlling surface runoff and erosion in rubber plantations on tropical mountain slopes, SW China. Catena 2017, 149, 167-175. [CrossRef]

38. Gomez, J.; Nearing, M.; Giraldez, J.; Alberts, E. Analysis of sources of variability of runoff volume in a 40 plot experiment using a numerical model. J. Hydrol. 2001, 248, 183-197. [CrossRef]

39. Ali, G.A.; L'Heureux, C.; Roy, A.G.; Turmel, M.; Courchesne, F. Linking spatial patterns of perched groundwater storage and stormflow generation processes in a headwater forested cachment. Hydrol. Process. 2011, 25, 3843-3857. [CrossRef]

40. Sidle, R.C. Shallow groundwater fluctuations in unstable hillslopes of coastal Alaska. Z. Gletscherkunde Glazialgeol. 1984, 20, 79-95.

41. Jeong, J.; Park, E.; Han, W.S.; Kim, K.Y.; Suk, H.; Jo, S. A generalized groundwater fluctuation model based on precipitation for estimating water table levels of deep unconfined aquifers. J. Hydrol. 2018, 562, 749-757. [CrossRef] 
42. Park, E.; Kim, K.Y.; Ding, G.; Kim, K.; Han, W.S.; Kim, Y.; Kim, N. A delineation of regional hydraulic conductivity based on water table fluctuation. J. Hydrol. 2011, 399, 235-245. [CrossRef]

43. Millar, D.J.; Coopera, D.J.; Ronaynec, M.J. Groundwater dynamics in mountain peatlands with contrasting climate, vegetation, and hydrogeological setting. J. Hydrol. 2018, 561, 908-917. [CrossRef]

44. Bowles, J.E. Foundation Analysis and Design, 5th ed.; The McGraw-Hill Companies, Inc.: Singapore, 1996; pp. 1-1169. ISBN 0-07-118844-4.

(c) 2018 by the authors. Licensee MDPI, Basel, Switzerland. This article is an open access article distributed under the terms and conditions of the Creative Commons Attribution (CC BY) license (http://creativecommons.org/licenses/by/4.0/). 